\title{
Afectarea cardiovasculară în boala Pompe
}

\author{
Alina-Costina Luca', Elena Braha² \\ ${ }^{1}$ Secţia Clinică de Cardiologie Pediatrică, Spitalul Clinic de Urgenţe pentru Copii „Sf. Maria“, Universitatea \\ de Medicină şi Farmacie „Gr. T. Popa“, Iaşi, România \\ ${ }^{2}$ Cabinetul de Genetică Medicală, Spitalul Clinic de Urgenţe pentru Copii „Sf. Maria“, Universitatea de \\ Medicină şi Farmacie „Gr. T. Popa“, Iaşi, România
}

\begin{abstract}
REZUMAT
Bolile lizozomale reprezintă un grup divers de boli monogenice care sunt definite prin defecte în funcționarea lizozomilor. Afectarea cordului face parte din fenotipul clinic al bolilor lizozomale. Boala Pompe este marcată de absența/deficitul enzimei lizozomale alfa-glucozidază şi prin vârsta diferită de debut clinic. Forma infantilă este definită de scăderea forței musculare şi hipertrofie cardiacă progresivă, urmate de insuficiență cardiacă progresivă. Boala Pompe necesită intervenție terapeutică imediată pentru a creşte potențialul beneficiu al terapiei enzimatice, cu îmbunătățirea secundară a fenotipului. Articolul prezintă semnele clinice şi cardiace sugestive pentru boala Pompe.
\end{abstract}

Cuvinte cheie: boli lizozomale, boala Pompe, cardiomiopatie

\section{Bolile lizozomale}

Lizozomii sunt organite citoplasmatice, $\mathrm{cu}$ o singură membrană fosfolipidică bilamelară, ce conțin enzime hidrolitice. Bolile lizozomale (BL) sunt un grup divers de boli monogenice (cele mai multe cu transmitere recesivă, câteva cu transmitere legată de X) care sunt consecința unei defect în funcționarea lizozomilor, definit prin acumularea de macromolecule nedigerate/parțial digerate care produc disfuncție celulară şi secundar o patologie multisistemică (1).

BL au o frecvență de aproximativ $1 / 8.000$ de nou-născuți vii (2). BL sunt cel mai frecvent datorate lipsei hidrolazei lizozomale dar, recent, au fost identificate defecte în proteinele modificatoare post-translațional, proteinele activatoare sau proteinele de trafic lizozomal (3).

Recent BL au fost clasificate după defectul molecular prezent la pacient (defecte în degradarea glicanilor, a lipidelor, a proteinelor, defecte în transportorii lizozomali sau în traficul lizozomal) $(4,5)$.

Din punct de vedere clinic, asocierea dintre elementele dismorfice (facies grosier, macroglosie), anomaliile osoase (disostoză), anomaliile cardiace (aritmie, cardiomegalie), hepatosplenomegalie şi simptomele neurologice (retard în dezvoltare, hipotonie, epilepsie, neuropatie periferică, retard mental, ataxie/spasticitate) pot sugera cu tărie suspiciunea clinică de BL. Clasic simptomele sunt progresive (6).

Testul enzimatic este posibil pentru BL. Testele moleculare pot confirma diagnosticul enzimatic şi pot clarifica varianta genetică, informație importantă în evaluarea terapiei de substituție enzimatică (4).

Sfatul genetic pentru un cuplu cu risc include testarea prenatală în vilozitățile coriale sau amniocite. BL sunt moştenite autosomal recesiv, cu excepția bolii Fabry, sindromului Hunter şi Danon care sunt boli legate de X (4).

\section{Boala Pompe}

Boala Pompe (boala de stocaj a glicogenului tip II) este o boală autosomal recesivă cu implicare multisistemică şi hipotonie neuromusculară progresivă, datorată unei mutații în gena pentru acidalfa-1,4 glucozidază (cromosomul 17q25.3) (7).

Incidența estimată a bolii Pompe (BP) este de $1 / 40.000$ (8). Forma de tip adult al BP are o inci- 
dență de 1/57.000 de nou-născuți pe an (9). Incidența persoanelor purtătoare este de 1/138.000 pentru forma clasică de boală şi de $1 / 57.000$ pentru forma cu debut tardiv (10). Forma cu debut infantil pare a fi mai frecventă la afro-americani, în China şi Taiwan (11), în timp ce forma de tip adult este mai frecventă în Olanda (8).

În forma clasică de BP cu debut infantil pacientul prezintă hipotonie severă (20-63\% dintre cazuri), anomalii cardiace cu insuficiență cardiacă congestivă (50-92\% cazuri), macroglosie, dificultăți de alimentație (44-97\% cazuri) şi probleme respiratorii (27-78\% cazuri) (12-14).

Forma non-clasică a BP cu debut infantil se manifestă în primul an de viaţă cu retard motor şi hipotonie musculară progresivă. În mod normal, afectarea cardiacă este uşoară $(14,15)$.

Forma cu debut tardiv a BP poate fi suspicionată la pacienții cu slăbiciune musculară proximală şi insuficiență respiratorie, fără o afectare cardiacă aparentă (15). Această formă se manifestă după vârsta de 27-41 de ani, dar manifestările precoce ale bolii preced diagnosticul cu 3-10 ani din cauza progresiei lente şi relativ nespecifice a simptomelor $(16,17)$.

Semnele clinice trebuie întotdeauna confirmate prin teste suplimentare. Testele nespecifice includ creatinfosfokinaza serică (crescută în forma clasică de BP şi normală în forma cu debut la adult) (18) şi a tetrazaharidelor urinare care sunt înalt sensibile, dar nespecifice pentru BP (19).

Testul specific constă în evaluarea activității enzimei acid alfa-glucozidază (GAA) în mostra de sânge uscat, enzimă ce are o activitate scăzută. Testul se efectuează înaintea iniţierii terapiei. Testul standard este reprezentat de activitatea enzimatică GAA în cultura de fibroblaşti din piele sau din muşchi, dar este un test dificil de efectuat $(20,18)$. Testul molecular ajută la confirmarea diagnosticului de BP şi este în mod special utilizat în familiile în care a fost diagnosticat deja un caz cu BP şi se încearcă identificarea purtătorilor genei mutante în scopul acordării sfatului genetic (18).

Terapia de substituţie enzimatică cu acid $\alpha$-glucosidază umană recombinantă conduce la prelungirea supraviețuirii şi îmbunătăţirea funcției cardiace. (21) Unele studii relevă faptul că beta blocantele, cum ar fi propranololul, pot reduce eficacitatea tratamentului enzimatic prin modularea expresiei receptorului (22).

Din punctul de vedere al cardiologului, BP reprezintă o importantă cauză familială de cardiomiopatie hipertrofică (23). Funcția şi structura cardia- că trebuie evaluate prin ecocardiografie, EKG şi monitorizare Holter (24).

Forma clasică cu debut infantil a BP este caracterizată de prezența cardiomiopatiei hipertrofice (septală sau concentrică) în $88 \%$ dintre cazuri, cardiomegalie în 92-100\% dintre cazuri, hipertrofie ventriculară stângă în $83-100 \%$ dintre cazuri, cu sau fără obstrucția tractului de ieşire a ventriculului stâng şi anomalii pe EKG $(13,14)$. Cardiomiopatia este datorată acumulării intracelulare de glicogen, ceea ce conduce la hipertrofie celulară şi scăderea funcției sistolice (25). În 2008, Levin J.C. et al, raportează regresia hipertrofiei ventriculare stângi şi îmbunătățirea fracției de ejecție după tratamentul de substituție enzimatică cu alfa-aglucozidază (25).

Acumularea glicogenului implică, de asemenea, şi sistemul de conducere cardiac (nodulul AV şi celulele fasciculului Hiss). Cele mai frecvente anomalii EKG sunt sindroamele de pre-excitaţie (scurtare PR în 10\% dintre cazuri, unde delta) pe Holter EKG de 24 de ore (26), sindromul Wolff-Parkinson-White $(27,28)$, blocuri atrio-ventriculare şi blocuri de ram în $4 \%$ dintre cazuri $(26,29)$.

Mecanismul patogenic ce implică sindromul Wolff-Parkinson-White nu este pe deplin cunoscut. $\mathrm{Au}$ fost emise unele ipoteze pentru a explica anomalia: sistemul de conducere este direct afectat de acumularea intracelulară de glicogen sau inelul fibros este întrerupt anatomic de acumularea de glicogen $(28,17)$. Unii autori raportează creşterea BNP plasmatic (peptidul natriuretic tip B) care pare a fi legat de severitatea afectării cardiace (30).

Forma non-clasică cu debut infantil al BP are manifestări clinice mai puțin severe ce devin evidente după vârsta de 1 an. Ecocardiografia relevă cardiomiopatie hipertrofică, mai puțin severă decât în forma clasică şi lipsa obstrucției sau a disfuncției diastolice ventriculare (31).

BP cu debut tardiv se poate manifesta la orice vârstă prin hipotonie musculară şi insuficiență respiratorie. Unii pacienți pot prezenta arteriopatie şi anevrisme ale arterelor carotide interne şi bazilare sau dilatarea aortei ascendente datorate acumulării de glicogen în musculatura vasculară (32-34). Pacienții pot fi asimptomatici sau pot avea simptome neurologice nespecifice (atacuri ischemice tranzitorii şi paralizii de nerv oculomotor) (33).

Unele studii publicate relativ recent au raportat la adult scurtarea intervalului PR în 10\% dintre cazuri şi o scădere a funcției sistolice a ventriculului stâng în 7\% dintre cazuri (26). Anestezia la pacienții cu BP poate precipita apariţia aritmiilor, determină vasodilatație şi reducerea contractilităţii miocardice (35). 
Hipotiroidia şi hipotiroidia subclinică au o prevalență mai mare la pacienții cu BP cu debut tardiv comparativ cu populația generală, ceea ce ar putea complica afectarea cardiacă pre-existentă (36).

În concluzie, evaluarea cardiacă de rutină prin ecocardiografie în BP este o parte importantă a ma- nagementului BP, poate urmări progresia bolii şi răspunsul la tratament. Ecocardiografia trebuie efectuată de un cardiolog pediatru cu experiență în BP. Ca o evaluare diagnostică de bază, în BP trebuie efectuat EKG pe 24 de ore în ambulator pentru a decela posibilele aritmii. 